\title{
Drug Interaction between Ginseng Extract (GE) and Sorafenib
}

\author{
Nam-Hee Lee ${ }^{1,2^{+}}$, Ho-Jae Park ${ }^{1+}$, Ja-Sung Rho', Mi-Kyung Kim², Yu-Kyoung Lee ${ }^{2}$, Euna Cho ${ }^{2}$, \\ Jeong $\mathrm{HeO}^{3}$, Mong $\mathrm{Cho}^{4}$ and Tae-Ho Hwang ${ }^{1,2_{\star}}$ \\ ${ }^{1}$ Department of Pharmacology, Pusan National University School of Korean Medicine, Yangsan 620-770, Korea \\ ${ }^{2}$ National Research and Development Center for Hepatobiliary Diseases, Pusan National University Yangsan Hospital, Yangsan 620-770, Korea \\ ${ }^{3}$ Department of Gastroenterology, Pusan National University Hospital, Busan 602-739, Korea \\ ${ }^{4}$ Department of Gastroenterology, Pusan National University Yangsan Hospital, Yangsan 620-770, Korea
}

Received October 6, 2011 /Revised November 1, 2011 /Accepted November 1, 2011

\begin{abstract}
Sorafenib is the only approved systemic, therapeutic agent for hepatocellular carcinoma (HCC). The use of Ginseng Extract (GE) in cancer patients is growing worldwide; however, drug interaction between sorafenib and GE has not been illuminated. Four different human cancer cell lines including HepG2 were used and immunocompetent mice were implanted subcutaneously with a mouse HCC cell line. Treatment with low dose GE stimulated cell growth, while a high dose inhibited growth. pERK (phosphorylation of extracellular signal-regulated kinase) was concomitantly increased and decreased respective of different doses of GE. Antitumoral effect of sorafenib decreased in non-proliferating phase cells but was sensitized after low dose GE (LDG) treatment. PD98059 (ERK phosphorylation inhibitor) efficiently blocked ERK phosphorylation, resulting in loss of sorafenib sensitization even after LDG treatment. In the HCC mouse model, LDG alone slightly increased tumor size while sorafenib alone significantly decreased it. However, a combination of LDG and sorafenib significantly decreased tumor size compared with sorafenib alone. Increase of pERK was observed in some normal mice organs and mild inflammatory change was observed in some of these organs, suggesting pERK activation by LDG may cause unexpected toxicity in normal cells. GE, dose-dependently, induced stimulation or inhibition in some human cancer cell lines. Combinational use of GE and sorafenib possibly potentiated an antitumoral response to sorafenib. pERK level has been provided as a potential predictive marker for sorafenib. Our result may suggest GE's dual effects in relation to pERK level in HCC cancer cell lines, and that certain doses of GE can sensitize sorafenib.
\end{abstract}

Key words : Sorafenib, pERK, Ginseng Extract, biomarker, drug interaction

\section{Introduction}

Sorafenib tosylate (Nexavar®, Bayer Pharmaceuticals Corp.) is an oral small molecule muti-kinase inhibitor, the only approved systemic therapeutics for hepatocellular carcinoma to date [1]. Recent clinical studies revealed that compared with placebo, administration of sorafenib monotherapy prolongs progression-free survival, time to tumor progression and overall survival in patients with advanced renal-cell carcinoma [2] and hepatocellular carcinoma [3]. Sorafenib inhibits several Raf kinase isoforms and the vascular endothelial growth factor and platelet-derived growth factor receptor families [4]. In cancer cells, multiple intracellular downstream signaling pathways such as

\footnotetext{
*Corresponding author

Tel : +82-51-510-7551, Fax : +82-51-510-7558

E-mail : thhwang@pusan.ac.kr

${ }^{+}$These authors contributed equally to this work
}

RAS/RAF/MEK/ERK and PI3K/Akt can be deregulated in various ways. By inhibiting phosphorylation of MEK and ERK, sorafenib has shown efficacy against various cancers [5]. However, due to limited survival benefits of sorafenib alone, several research attempts are underway to investigate synergic or additive therapeutic effects by combining anti-cancer agents and to find out the finest mixture at a pharmacokinetic and/or pharmacodynamic level.

As there is yet to be a drug, which potentially synergizes sorafenib effect, sorafenib taking patients are increasingly attempting to take unproven alternative medicines such as vitamin and herbs, concomitantly. This tendency can be vividly observed in patients taking orally-consumed cancer therapeutics such as sorafenib or sunitinib, which can be taken at the patient's convenience. In a survey of 453 cancer patients, $76.6 \%$ of patients used alternative medicines with traditional cancer treatments [6]. Among those, ginseng extract (GE) is one of the most popular herbs which cancer 
patients have access to. Ginseng, the root and rhizome of Panax ginseng C.A. Meyer (Araliaceae), reportedly has a myriad of demonstrated effects with regards to cancer, such as anti-angiogenesis, anti-proliferation and apoptosis [7,8]. GE as an independent anti-proliferative agent $[9,10]$ or as a chemotherapy adjuvant $[6,11]$, has been demonstrated to inhibit many types of cancer: ovarian, breast, lung, melanoma $[12,13]$ in non-clinical animal models. However, there is no clear evidence that GE can provide clinical benefits in cancer patients except in cases of reduced cancer-related fatigue and stress in randomized controlled trials [14]. Furthermore, GE was reported to stimulate cell growth in some types of cancer cells such as $\mathrm{ER}(+)$ breast cancer and endometrial cancer [15]. Taken together, the usefulness of GE for cancer patients as a single agent and/or as an adjuvant should be urgently illuminated.

\section{Materials and Methods}

\section{Chemicals}

GE (KOREAN RED GINSENG EXTRACT ${ }^{\circledR}$ ), which was purchased from Korea Ginseng Corporation (Daejeon, Korea), is an approved health supplement by Korea FDA. This GE was manufactured by a steaming method which is more widely used in Asia and USA [16]. The stock solutions of GE for in vitro study were dissolved in cell culture media then filtered through $0.45 \mu \mathrm{m}$ sterilized filter and stored at $-20^{\circ} \mathrm{C}$ after aliquot in $4 \% \mathrm{v} / \mathrm{v}$ doses. Saponin, bioactive components of GE, was approximately $0.03 \%$ in the information sheet provided by the company. Research grade pure Sorafenib was purchased from LC laboratories (Woburn, MA) and dissolved in DMSO (Sigma Aldrich) to give a stock solution of $100 \mathrm{mg} / \mathrm{ml}$ and further dilutions were made in culture media, with final concentrations of DMSO not exceeding $0.1 \mathrm{v} / \mathrm{v} \%$. The stock solutions were stored at $-20^{\circ} \mathrm{C}$.

\section{Cell lines}

Human hepatocellular carcinoma cell line, HepG2; human ovarian cancer cell line, A2780; human prostate adenocarcinoma cell line, PC-3; human renal carcinoma cell line SNU-482 and mouse hepatoculluar carcinoma cell line TIB-75 were obtained from ATCC. A2780, HepG2, PC-3, and TIB-75 cells were cultured in DMEM (Dulbecco's modified Eagle's Medium) and SNU-482 was cultured in RPMI-1640 (Roswell Park Memorial Institute-1640 medium), containing
$10 \%$ fetal bovine serum (Hyclone), 100 units $/ \mathrm{ml}$ penicillin and $100 \mathrm{mg} / \mathrm{ml}$ streptomycin. The cells were incubated at $37^{\circ} \mathrm{C}$ in a humidified atmosphere containing $5 \% \mathrm{CO}_{2}$. Cells were seeded in $175 \mathrm{~cm}^{2}$ cell culture flasks and the medium was changed every other day.

\section{Measurement of cell growth Cell}

Counting Kit-8 (CCK-8, Dojindo Molecular Technologies, Inc., Japan) was used in accordance with a company provided manual to determine cell growth. In brief, the cells were plated in 96-well plates 1 day before treatment; pre-incubated cells were washed with PBS and treated with 100 $\mu \mathrm{l}$ of various concentrations of GE and/or sorafenib for 24 hr. After PBS washing, $10 \mu \mathrm{l}$ of CCK-8 was added to the cells and plated for $2 \mathrm{hr}$ in a humidified incubator (at $37^{\circ} \mathrm{C}$, $5 \% \mathrm{CO}_{2}$ ), after which their absorbance at $450 \mathrm{~nm}$ were measured using ELISA reader (ELx808TM Absorbance Microplate Reader, Biotech). The percentage of viable cells was calculated as the ratio of viable cells to total cells absorbance measurements $\times 100$. Cell cycle Propidium iodide staining was performed to analyze cell cycle distribution. $1 \times 10^{6}$ A2780, HepG2 or PC-3 cells were seeded in $100 \mathrm{~mm} \times 20$ $\mathrm{mm}$ cell culture dish (Corning, NY) and incubated at $37^{\circ} \mathrm{C}$ for $24 \mathrm{hr}$ in a humidified atmosphere containing $5 \% \mathrm{CO}_{2}$. Cells were fixed in $70 \%$ cold ethanol over an hour. After double washing with PBS, cells were stained with $50 \mathrm{\mu g} / \mathrm{ml}$ propidium iodide (Invitrogen) solution in the presence of $20 \mu \mathrm{l} \mathrm{of} 10 \mathrm{mg} / \mathrm{ml}$ RNase A (Sigma) over $30 \mathrm{~min}$ at $4{ }^{\circ} \mathrm{C}$ followed by detection of signals using high-performance flow cytometer, BD FACSCanto II (Becton Dickinson). [17]

\section{Measurement pERK level}

After cells were lysed in PRO-PREPTM Protein Extraction Solution (iNtRON: $1.0 \mathrm{mM}$ PMSF, $1.0 \mathrm{mM}$ EDTA, $1 \mu \mathrm{M}$ Pepstatin A, $1 \mu \mathrm{M}$ Leupeptin, $1 \mu \mathrm{M}$ Aprotinin), protein concentration of each sample was determined by BCA Protein Assay Reagent (Thermo). $10 \mu \mathrm{g}$ of proteins were loaded on $10 \%$ SDS-polyacrylamide gel and transferred to polyvinylidene difluoride filters (Millipore). The filter was blocked and then incubated with Anti-pERK antibody or Anti-ERK antibody (Santa Cruz Biotechnology) at 1:500 in 1\% BSA-TBST (10 mM Tris-Cl, pH 7.5, $150 \mathrm{mM} \mathrm{NaCl}, 0.05$ $\%$ Tween 20) for $1 \mathrm{hr}$ and $30 \mathrm{~min}$. After washing, the blots were incubated with secondary antibody $(200 \mathrm{ug} / 0.5 \mathrm{ml}$, Santa Cruz Biotechnology) conjugated to horseradish perox- 
idase at $1: 1,000$ in $1 \%$ BSA-TBST for $40 \mathrm{~min}$. Proteins were visualized and quantified by Chemiluminescence image system (Davinch-chemiTM) according to the manufacturer's instruction. In preparation of pERK level testing in vivo, HCC cell line bearing mice were randomized into one of four groups ( $n=6$ per group) and given the following treatment for 6 days (daily): (1) PBS alone, (2) sorafenib alone $(500 \mu \mathrm{g}),(3) \mathrm{GE}$ alone $(1 \mu \mathrm{g}),(4) \mathrm{GE}$ alone $(10 \mu \mathrm{g})$, (5) simultaneous treatment of sorafenib $(500 \mu \mathrm{g})$ and GE $(1 \mu \mathrm{g})$, and (6) simultaneous treatment of sorafenib (500 $\mu \mathrm{g})$ and GE (10 ug). All mice were sacrificed on day 6 at $4 \mathrm{hr}$ post treatment on that day, and tumor as well as normal organs such as heart, kidney, lung, liver, brain, stomach and colon were stored at $-80^{\circ} \mathrm{C}$.

Measurement of cell growth by ex vivo treatment of serum obtained from ginseng fed mouse (SGFM) or PBS fed mouse (SPFM)

Mice were housed, cared for and used in experiments as approved by the Ethical committee for Animal study at Pusan National University. After daily feedings of PBS or GE $(100 \mu \mathrm{g} /$ day) for 3 days which is 100 folds higher than that of human equivalent dosage, the mice $(n=3$ for each group) were sacrificed to obtain serum from each. For in vitro cell growth assay, differential proportion of SGFM was mixed with SPFM to a total of $20 \%$ serum in final concentration.

\section{Mouse syngeneic tumor model}

Immunocompetent mice (BALB/c mice) were implanted subcutaneously with mouse HCC cell line (TIB-75, $1 \times 10^{6}$ cells). Once tumors reached $50-100 \mathrm{~mm}^{3}$, animals were regrouped and treated as indicated above. Tumor sizes were followed by caliper measurement and animals were euthanized when tumors reached $1.4 \mathrm{~cm}^{3}$.

\section{Statistical analysis}

Values are given as mean \pm SD (standard deviation). Statistical evaluations of data were analyzed using student $t$ test. $P$ value of less than 0.05 was defined as statistically significant.

\section{Results and Discussion}

Growth effects on human cancer cell lines were observed after treatment of GE alone $(0.005-0.2 \%$ range) or con- comitantly with sorafenib (Fig. 1). Based on Phase 2 pharmacokinetic information on sorafenib [18], serum therapeutic dose of 1 or $10 \mu \mathrm{g} / \mathrm{ml}$ was used in vitro study. By the company's recommending daily dosage of GE (1-3 g/day) for adults, it is assumed that the peak serum dose should be far less than $0.2 \%$. Accordingly, $0.005 \%$ to $0.2 \%$ doses of GE were used in this study.

Among four different human cancer cell lines tested in this study, either growth stimulation or inhibition was observed in a dose dependent pattern after $24 \mathrm{hr}$ treatment of GE in SNU-482, HepG2 and A2780 (Fig. 1). Combinational treatment of sorafenib and GE lowered the cell growth curve indicating an additive effect. Re-plotting of the combination effect of sorafenib $(1 \mu \mathrm{g} / \mathrm{ml}$ or $10 \mu \mathrm{g} / \mathrm{ml})$ and GE $(0.025 \%$ or $0.1 \%)$ on the cell growth is shown in Fig. 2. Sorafenib treatment $(1 \mu \mathrm{g} / \mathrm{ml})$ alone had a less therapeutic effect than when treated concomitantly with GE (even with growth stimulating doses as a single agent namely $0.0125 \%$ to $0.1 \%$ ), the latter causing synergistic inhibition of A2780 and SNU-482 growth. These results were more evident when the dose of sorafenib was increased to $10 \mu \mathrm{g} / \mathrm{ml}$ within the combination.

The combinational effect of sorafenib and GE was tested in different cell densities to determine the correlation with cell growth (Fig. 3). The two doses of sorafenib $(1 \mathrm{\mu g} / \mathrm{ml}$ or $10 \mu \mathrm{g} / \mathrm{ml}$ ) did not cause cell death in $100 \%$ A2780 cell density while they caused a dose dependent cell death in $60 \%$ A2780 cell density as anticipated, as sorafenib activity is dependent on cell proliferation and ERK activity $[19,20]$. However, even in $100 \%$ cell density (in a minimum cell proliferating signal), $10 \mu \mathrm{g} / \mathrm{ml}$ sorafenib could induce significant cell death after concomitant treatment of GE suggesting sorafenib sensitization may be related to stimulating the cell cycle by GE even in $100 \%$ cell density.

An important role of sorafenib is blocking of the Raf mediated ERK phosphorylation resulting in inhibition of cell growth. Accordingly, the profile of phosphorylation of ERK by GE alone or its combination with sorafenib was determined in HepG2 and A2780 (Fig. 4A). It was notable that ERK activity was significantly increased by $2 \mathrm{hr}$ treatment of GE $(0.005 \%$ to $0.125 \%)$ in HepG2 and A2780 cells. One notable observation uniquely found in A2780 cell was that ERK protein level was downregulated by treatment of GE alone while ERK phosphorylation was markedly increased. However, inhibition of ERK phosphorylation by sorafenib upregulated ERK protein level suggesting a feed- 

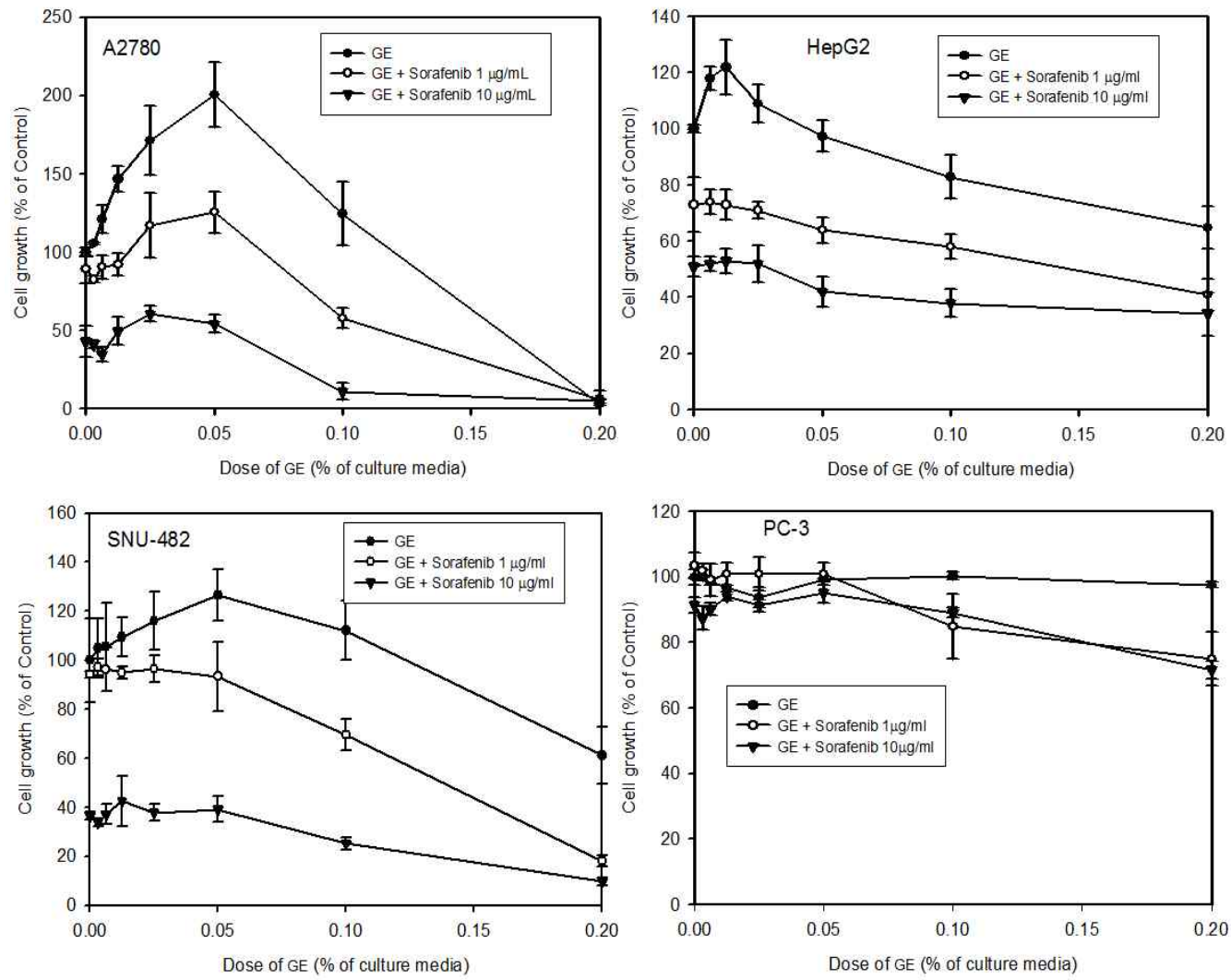

Fig. 1. Effects of sorafenib (24 hr treatment) on the proliferation of human cancer cell lines without or with different doses of ginseng extract (GE).
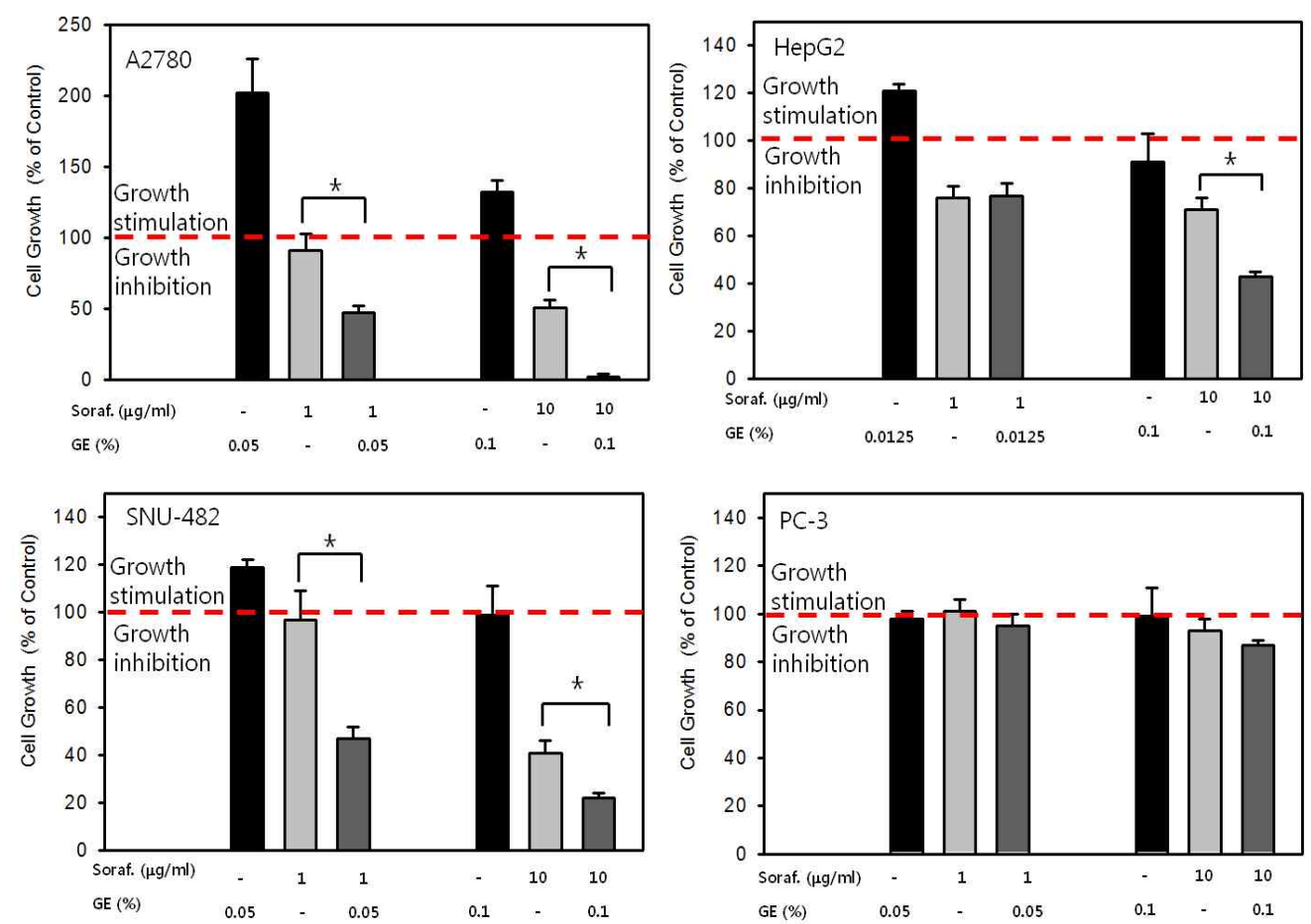

Fig. 2. Combinational growth effects of therapeutic doses of sorafenib $(1 \mu \mathrm{g} / \mathrm{ml}$ or $10 \mu \mathrm{g} / \mathrm{ml})$ and GE in human cancer cell lines $\left(\mathrm{n}=8,{ }^{*} p<0.01\right)$. 


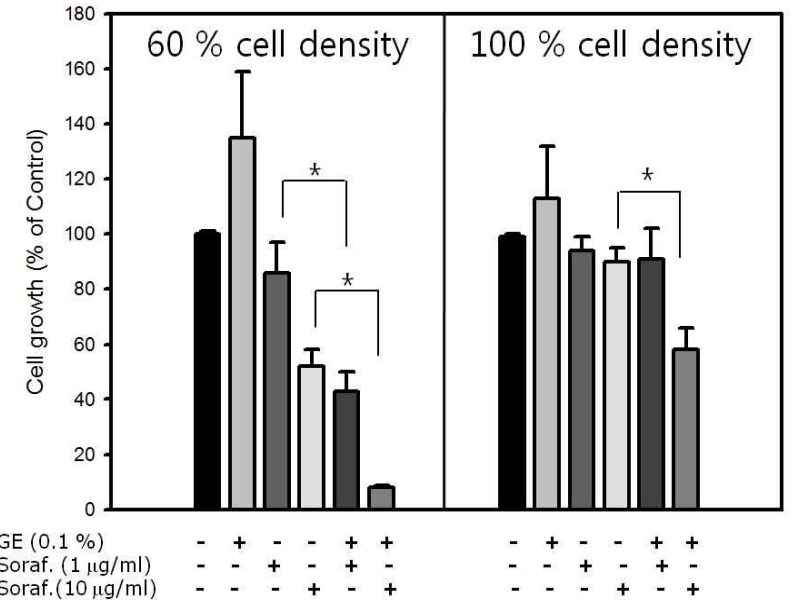

Fig. 3. Effects of cell density on the combinational effect of sorafenib and GE in A2780 cell growth $\left(\mathrm{n}=8,{ }^{*} p<0.01\right)$.

(A)

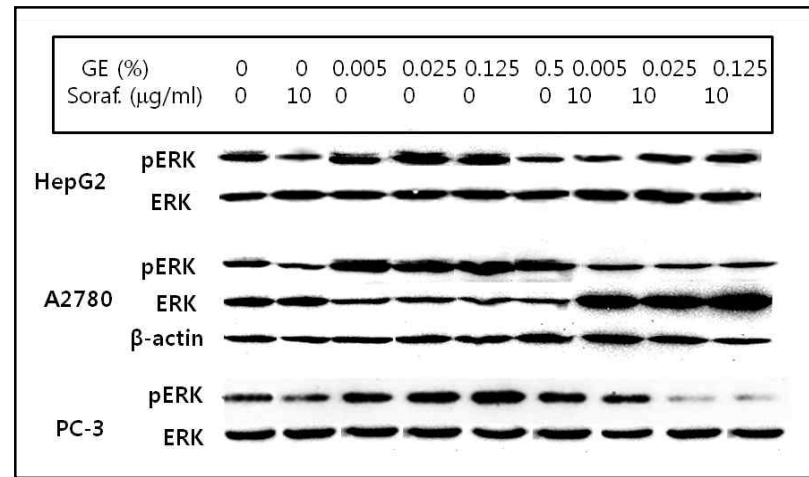

(B)

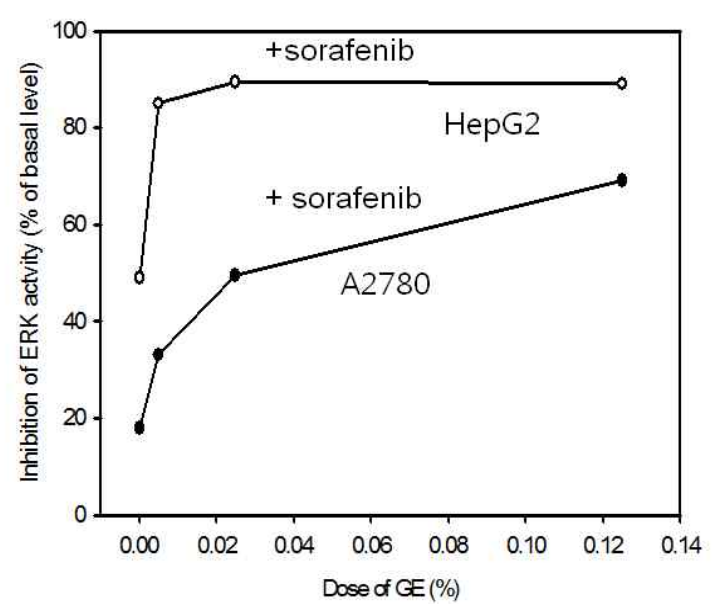

Fig. 4. Phosphorylation profile of ERK by changes in ERK activity with treatment of GE alone and/or sorafenib in human cancer cell lines (A) and inhibition of ERK phosphorylation by sorafenib dependent on GE doses in A2780 or HepG2 cells Quantification of ERK activity inhibition was displayed as \% of basal level activity in each (B).

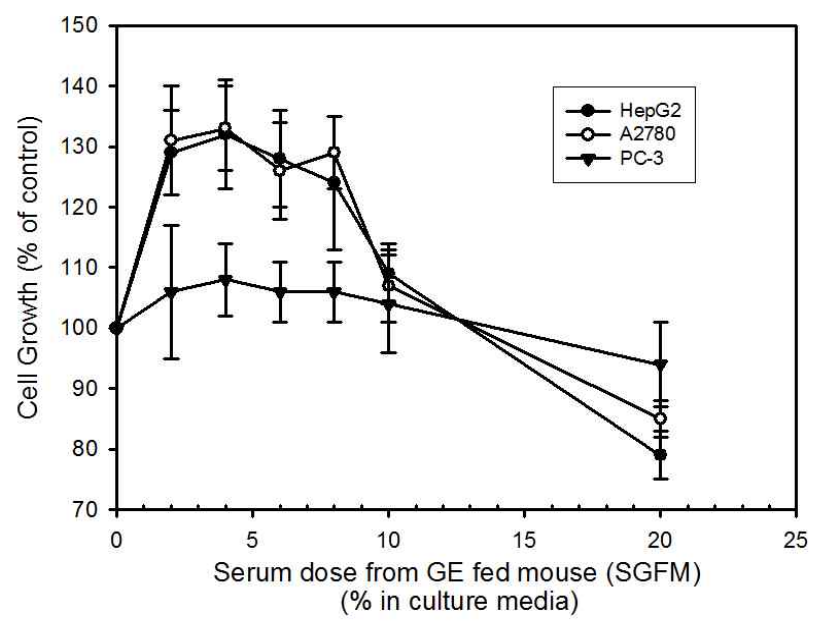

Fig. 5. Effects on cell proliferation by $20 \%$ serum with different proportion of serum obtained from high dose GE fed mouse (SFGM) and serum from PBS fed mouse (SPFM) (24 $\mathrm{H}$ treatment) were measured.

back between ERK protein level and ERK phosphorylation in A2780 cells. Although this finding is interesting, further analysis was not conducted on this as it was not primary purpose of this study. In the absence of sorafenib, the phosphorylation of ERK was stimulated according to the increase of GE doses, and the inhibition percentile in ERK phosphorylation seems to be dose-dependent of GE (Fig. 4B).

As GE is composed of more than 20 different active chemicals which have different pharmacokinetics [21,22], in vitro study using GE cannot reflect the effect of GE absorbed through the gastrointestinal tract. Accordingly, ex vivo study using serum obtained from GE fed mouse (SGFM) or serum obtained from PBS fed mouse (SPFM) was conducted (Fig. 5). At $4 \mathrm{hr}$ post treatment of high dose GE (1 mg/day) or PBS for 3 days ( $n=3$ for each group), mice were sacrificed. Cancer cell lines, upon ex vivo incubation with SGFM, induced dose-dependent stimulation or inhibition in the growth of A2780 cells or HepG2 cells. Though effects were mild in PC-3 cells, this signifies similar biological activity between whole GE and GE absorbed through the gastrointestinal tract. For the ex vivo study, 20\% of heat treated serum composed of both SGFM and SPFM was treated for $24 \mathrm{hr}$. For example, 2\% SPFM in Fig. 5 was used after addition of $18 \%$ SGFM.

To determine the combinational effect of sorafenib and GE in vivo animal model, TIB-75 mouse HCC syngeneic model was prepared as previously [23]. Human equivalent dosage of GE for each mouse (1 $\mathrm{\mu g} /$ day) mildly increased tumor growth ( $\mathrm{n}=5$ for each group) while simultaneous 
treatment of sorafenib (500 $\mu \mathrm{g} /$ day $)$ and GE $(1 \mu \mathrm{g} /$ day $)$ significantly inhibited tumor growth compared with that of sorafenib alone (Fig. 6). In a separate in vivo study, we verified that treatment of 10 or 50 folds of GE for human dose $(10 \mu \mathrm{g}$ or $50 \mu \mathrm{g} /$ day) significantly inhibited tumor growth (Fig. 7).

In this study, depending on doses of GE, GE induced either stimulation or inhibition on cell growth both in vitro and in vivo. Although pharmacokinetic information is lacking, orally taken GE may not reach its serum level to $0.05 \%$ if recommended oral dose is used. Therefore, we note that cell-proliferating effect of GE may possibly be close to the actual serum dose of GE absorbed in human. Most studies on GE have suggested an antitumoral effect in vitro and in vivo study with less focus on its concentration [10]; however, it is evident that high doses of GE $>0.1 \%$ in culture media)

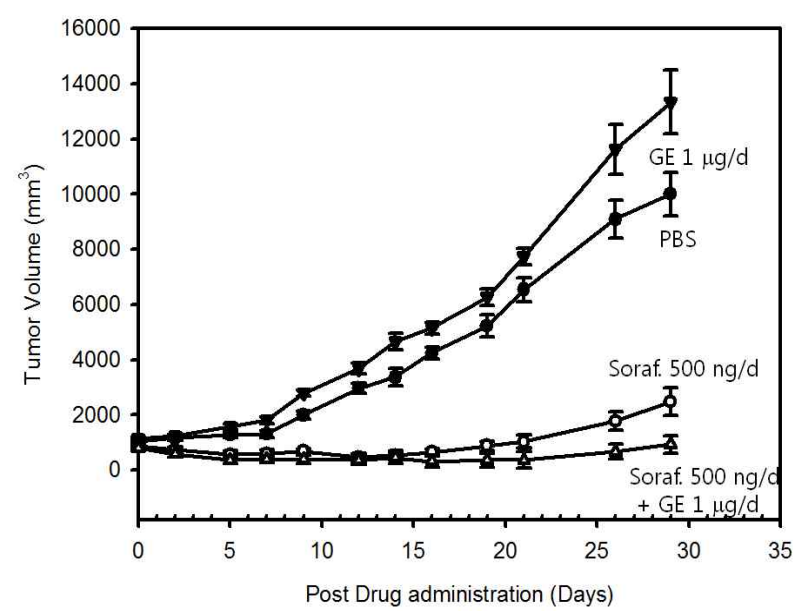

Fig. 6. Effects of GE and concomitant administration of GE and sorafenib in mouse syngeneic HCC model.

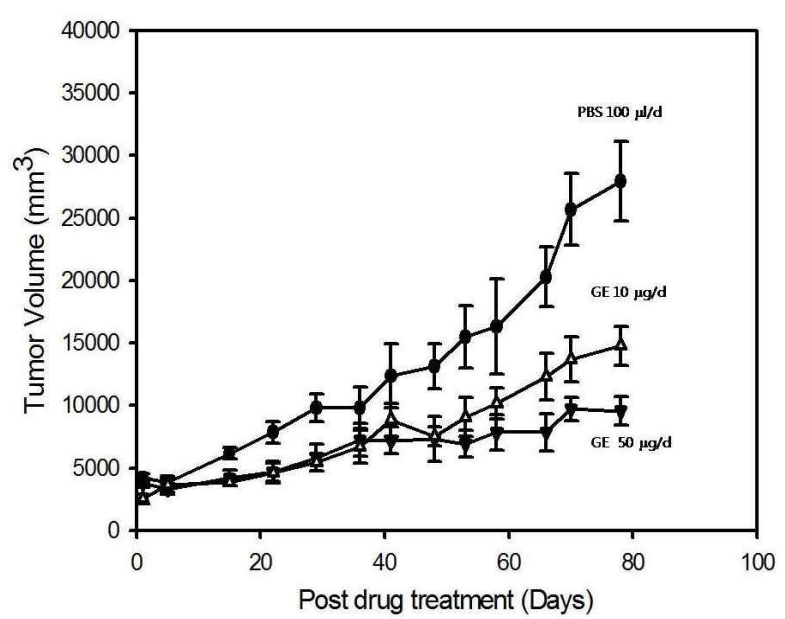

Fig. 7. Treatment of $10 \mathrm{mM}$ and $50 \mathrm{mM}$ GE. can kill cancer cell lines efficiently both in vitro and in vivo in this study (Fig. 1 and Fig. 7), but these doses may be beyond the peak serum level of GE in human.

In a HCC phase II study of sorafenib, 33 had their pre-treatment $\mathrm{pERK}$ levels evaluated, and pre-treatment tumor pERK levels were correlated with the time to tumor progression [20] indicating that pERK may be a useful biomarker for sorafenib. And in vitro cell line study, additional evidences were proposed that $\mathrm{PERK}$ level can be a potential biomarker as a predictor of sensitivity to sorafenib in treating HCC $[19,20]$. Furthermore, anti-proliferative activity of sorafenib varies widely depending on the oncogenic signaling pathways driving proliferation $[27,28]$ suggesting correlation of sorafenib sensitization of pERK level. In conclusion, we suggest a possible potentiation of antitumoral activity by combination of sorafenib and GE; however, we do not know its exact mechanism. In practice, there is a growing number of HCC patients who take GE with or without the knowledge of their physicians. So it is imperative that physicians be aware of the interactions between GE and sorafenib. What we have demonstrated in this study is very preliminary and can be defined as a pilot study. An extensive research and a well-designed clinical trial based on GE pharmacological kinetics data are crucial to elucidate the unknown mechanism.

\section{Acknowledgement}

This work was supported by a 2-Year Research Grant of Pusan National University.

\section{References}

1. Abou-Alfa, G. K., L. Schwartz, S. Ricci, D. Amadori, A. Santoro, A. Figer, J. De Greve, J. Y. Douillard, C. Lathia, B. Schwartz, I. Taylor, M. Moscovici, and L. B. Saltz. 2006. Phase II study of sorafenib in patients with advanced hepatocellular carcinoma. J. Clin. Oncol. 24, 4293-4300.

2. Alex, A. A., J. R. Molina, S. J. Mandrekar, R. Marks, J. R. Reid, G. Croghan, L. J. Hanson, J. R. Jett, C. Xia, C. Lathia, and R. Simantov. 2007. Phase I trial of sorafenib in combination with gefitinib in patients with refractory or recurrent non-small cell lung cancer. Clin. Cancer Res. 13, 2684-2691.

3. Chao, Z., Y. Shoyama, and T. Hiroyuki. 2006. Pharmacokinetic study of ginsenosides Rb1 and Rg1 in rat by ELISA using anti-ginsenosides $\mathrm{Rb} 1$ and $\mathrm{Rg} 1$ monoclonal antibodies. $\mathrm{Am}$ J. Chinese Med. 34, 1069-1081.

4. Chowdhury, S. J., M. G. Larkin, and M. E. Gore. 2008. Recent advances in the treatment of renal cell carcinoma 
and the role of targeted therapies. Eur. J. Cancer 44, 2152-2161.

5. Barton, D. L., G. S. Soori, B. A. Bauer, J. A. Sloan, P. A. Johnson, C. Figueras, S. Duane, B. Mattar, H. Liu, P. J. Atherton, B. Christensen, and C. L. Loprinzi. 2010. Pilot study of Panax quinquefolius (American ginseng) to improve cancer-related fatique: a randomized, double-blind, dose-finding evaluation: NCCTG trial N03CA. Support Care Cancer 18, 179-187.

6. DiGianni, L. M., J. E. Garber, and E. P. Winer. 2002. Complementary and alternative medicine use among women with breast cancer. J. Clin. Oncol. 20, 34S-38S.

7. Finn, R. S. 2010. Development of molecularly targeted therapies in hepatocellular carcinoma: where do we go now? Clin. Cancer Res. 16, 390-397.

8. Fishbein, A. B., C. Z. Wang, L. X. Li, S. R. Mehendale, S. Sun, H. H. Aung, and C. S. Yuan. 2009. Asian ginseng enhances the anti-proliferative effect of 5-Fluorouracil on human colorectal cancer: comparison between white and red ginseng. Arch Pharm Res. 32, 505-513.

9. Guida, T., S. Anaganti, L. Provitera, R. Gedrich, E. Sullivan, S. M. Wilhelm, M. Santoro, and F. Carlomagno. 2007. Sorafenib inhibits imatinibresistant KIT and platelet-derived growth factor receptor $\mathrm{h}$ gatekeeper mutants. Clin. Cancer Res. 13, 3363-3369.

10. Guo, T., N. P. Agaram, G. C. Wong, G. Hom, D. D’Adamo, R. G. Maki, G. K. Schwartz, D. Veach, B. D. Clarkson, S. Singer, R. P. DeMatteo, P. Besmer, and C. R. Antonescu. 2007. Sorafenib inhibits the imatinibresistant KITT670I gatekeeper mutation in gastrointestinal stromal tumor. Clin Cancer Res. 13, 4874-4881.

11. Heo, J., J. B. Caroline, A. Moon, C. W. Kim, R. Patt, M. K. Kim, Y. K. Lee, S. Y. Oh, H. Y. Woo, K. Parato, J. Rintoul, T. Falls, T. Hickman, B. G. Rhee, J. C. Bell, D. H. Kirn, and T. H. Hwang. 2011. Sequential therapy with JX-594, A targeted oncolytic poxvirus, followed by sorafenib in hepatocellular carcinoma: preclinical and clinical demonstration of combination efficacy. Mol. Ther. 19, 1170-1179.

12. Hoshino, R., S. Tanimura, K. Watanabe, T. Kataoka, and M. Kohno. 2001. Blockade of the extracellular signal-regulated kinase pathway induces marked G1 cell cycle arrest and apoptosis in tumor cells in which the pathway is constitutively activated. J. Biochem 276, 2686-2692.

13. Keating, G. M. and A. Santoro. 2009. Sorafenib: a review of its use in advanced hepatocellular carcinoma. Drugs 69, 223-240.

14. Kim, J. H., J. Y. Oh, B. H. Park, D. E. Lee, J. S. Kim, H. E. Park, M. S. Roh, J. E. Je, J. H. Yoon, S. H. Thorne, D. Kirn, and T. H. Hwang. 2006. Systemic armed oncolytic and immunologic therapy for cancer with JX-594, a targeted poxvirus expressing GM-CSF. Mol. Ther. 14, 361-370.

15. Koo, H. H., H. J. Jeong, I. Y. Choi, H. J. An, P. D. Moon, S. J. Kim, S. Y. Jee, J. Y. Um, S. H. Hong, S. S. Shin, D. C. Yang, Y. S. Seo, and H. M. Kim. 2007. Mountain grow ginseng induces apoptosis in HL-60 cells and its mechanism have little relation with TNF-alpha production. Am J. Chinese Med 35, 169-182.

16. Li, X. L., C. Z. Wang, S. R. Mehendale, S. Sun, Q. Wang, and C. S. Yuan. 2009. Panaxadiol, a puriWed ginseng component, enhances the anti-cancer eVects of 5-Xuorouracil in human colorectal cancer cells. Cancer Chemoth Pharm 64, 1097-1104.

17. Ling, Y., L. Yong, and L. Chang-Xiao. 2006. Metabolism and pharmacokinetics of ginsenosides. Asian J. PD and PK. 6, 103-120.

18. Sagar, S. M., D. Yance, and R. K. Wong. 2006. Natural health products that inhibit angiogenesis: a potential source for investigational new agents to treat cancer-Part 1. Curr. Oncol. $13,14-26$.

19. Shin, H. R., J. Y. Kim, T. K. Yun, G. Morgan, and H. Vainio. 2000. The cancer-preventive potential of Panax ginseng: a review of human and experimental evidence. Cancer Causes Control. 11, 565-576.4.

20. Wang, W., Y. Zhao, E. R. Rayburn, D. L. Hill, H. Wang, and R. Zhang. 2007. In vitro anti-cancer activity and structure-activity relationships of natural products isolated from fruits of Panax ginseng. Cancer Chemoth Pharm 59, 589-601.

21. Wang, X. T., J. L. Martindale, and N. J. Holbrook. 2000. Requirement for erk activation in cisplatin-induced apoptosis. J. Biochem 275, 9435-39443.

22. Wilhelm, S. M., C. Carter, L. Tang, D. Wilkie, A. McNabola, H. Rong, C. Chen, X. Zhang, P. Vincent, M. McHugh, Y. Cao , J. Shujath, S. Gawlak, D. Eveleigh, B. Rowley, L. Liu, L. Adnane, M. Lynch, D. Auclair, I. Taylor, R. Gedrich, A. Voznesensky, B. Riedl, L. E. Post, G. Bollag, and P. A. Trail. 2004. BAY 43-9006 exhibits broad spectrum oral antitumor activity and targets the RAF/MEK/ERK pathway and receptor tyrosine kinases involved in tumor progression and angiogenesis. Cancer Res. 64, 7099-7109.

23. Woessmann, W., X. B. Chen, and A. Borkhardt. 2002. Ras-mediated activation of ERK by cisplatin induces cell death independently of p53 in osteosarcoma and neuroblastoma cell lines. Cancer Chemoth Pharm 50, 397-409.

24. Yun, T. K. 2001. Panax ginseng - a non-organ-specific cancer preventive? Lancet Oncol. 2, 49-55.

25. Yun, T. K., S. H. Kim, and Y. S. Lee. 1995. Trial of new medium-term model using benzo-(a)pyrene induced lung tumor in newborn mice. Anticancer Res. 15, 839-846.

26. Yun, T. K., S. H. Kim, and Y. R. Oh. 1987. Medium-term (nine weeks) method for assay of preventive agents against tumor. J. Korean Cancer Assoc. 1-7.

27. Zhang, Z., X. Zhou, H. Shen, D. Wang, and Y Wang. 2009. Phosphorylated ERK is a potential predictor of sensitivity to sorafenib when treating hepatocellular carcinoma: evidence from an in vitro study. BMC Med 41.

28. $\mathrm{Zhu}, \mathrm{A}$. X. Predicting the response to sorafenib in hepatocellular carcinoma: where is the evidence for phosphorylated extracellular signaling-regulated kinase (pERK)? BMC Med 42. 


\section{초록 : 쏘라페닙과 홍삼추출물간의 약물상호작용}

이남희 ${ }^{1,2} \cdot$ 박호재 ${ }^{1} \cdot$ 노자성 ${ }^{1} \cdot$ 김미경 $^{2} \cdot$ 이유경 ${ }^{2} \cdot$ 조은아 ${ }^{2} \cdot$ 허정 $^{3} \cdot$ 조몽 ${ }^{4} \cdot$ 황태호 $^{1{ }^{2} \star}$

( ${ }^{1}$ 부산대학교 한의학전문대학원, ${ }^{2}$ 부산대학교, ${ }^{3}$ 부산대학교병원, ${ }^{4}$ 양산부산대학교병 원)

쏘라페닙은 간암 치료제로 승인된 유일한 약이다. 전세계 암환자들의 인삼추출물 사용이 증가 되고 있지만 쏘 라페닙과의 상호작용에 대한 연구는 부족하다. 사람의 간암 세포주와 생쥐 모델을 사용하여 쏘라페닙과 인삼추 출물의 약물 상호작용을 알아보고자 하였다. 저농도 인삼추출물 투여시 암세포주의 성장과 $\mathrm{pERK}$ (phosphorylation of extracellular signal-regulated kinase)의 증가가 관찰되었고 고농도 투여시 암세포 억제와 $\mathrm{pERK}$ 감소가 관찰되었다. 성장 사이클이 없는 세포에서 쏘라페닙의 항암 효과가 감소한 반면 저농도 인삼 투여 시 항암 효능이 증진되어 나타났다. PD98059 (ERK 인산화 억제재)은 효과적으로 ERK 인산화를 억제하여 인삼추 출물의 쏘라페닙 감작 작용을 억제시켰다. 생쥐 간암 세포주 모델에서, 저농도 인삼추출물은 다소 암세포 크기를 증가 시켰지만 고농도 투여시 감소시켰다. 그러나, 인삼추출물과 쏘라페닙 동시 투여시 항암 효능은 현저히 증가 되었다. 정상조직에서 저농도 인삼에 의해 PERK 증가가 관찰되었으며 이것은 홍삼에 의한 독성 증가와 관련될 것으로 추정되었다. 결론적으로 인삼추출물과 쏘라페닙은 농도에 따라 항암효능을 증가 시킬 수 있음을 보여 주 었지만 독성의 가능성도 함께 증가시켰다. 인삼추출물과 쏘라페닙 약물 상호작용에 대한 더 면밀한 연구가 필요 할 것으로 보인다. 